\title{
Introduction to this Special Issue on \\ Strata Formation on \\ European Margins \\ A Tribute to EU-NA Cooperation in Marine Geology
}

\author{
BY JAMES P.M. SYVITSKI, PHILIP P.E. WEAVER, SERGE BERNÉ, \\ CHARLES A. NITTROUER, FABIO TRINCARDI, AND MIQUEL CANALS
}

In the early fall of 1998, we sat gazing over the coastal ocean that surrounds Sicily. Scientists from around the world had gathered to participate in a SEPM-IAS (Society for Sedimentary Geology-International Association of Sedimentologists) research conference called "Strata and Sequences on Shelves and Slopes" otherwise known as STRATACON '98. Our hosts, Michael Field (U.S. Geological Survey) and Albina Colella (University di Catania), did all that they could to foster scientific exchange among the participants. The spirit led to a break-through side meeting of those representing the interests of the U.S. Office of Naval Research (ONR) and those representing the European Commission (EC). The unfortunate drift away from coordinated research between European Union (EU) and North American (NA) agencies was duly noted. Subsequent coordination meetings over the next three years led to the birth of the EuroSTRATAFORM cluster and related projects. EurOSTRATAFORM had five goals:

1. To evaluate the influences on continental-margin sediment flux, including the characteristics of sediment sources and their temporal variability due to climatic evolution and human impacts.

2. To understand the oceanic processes that erode, transport and deposit sediment in the margin system, including short-term (i.e., hours to weeks) processes that produce event beds and the longer-term variability (e.g., seasonal, interannual) of those processes.

3. To quantify the physical and biological processes responsible for post-depositional modification of strata.

4. To understand the creation of the preserved stratigraphic architecture and sedimentary facies on continental margins as the product of processes acting with spatial and temporal heterogeneities.

5. To explore the nested expression of sedimentary successions, including the geologic identities of seismic properties, sequence boundaries, and intervening sequences.

James P.M. Syvitski is Director, Institute of Arctic and Alpine Research, University of Colorado, Boulder, United States of America. Philip P.E. Weaver is Professor, Southampton Oceanography Centre, United Kingdom. Serge Berné is Senior Research Scientist, Institut français de recherche pour l'exploitation de la mer (IFREMER), Plouzané Cedex, France.

Charles A. Nittrouer is Professor, School of Oceanography, School of Oceanography, University of Washington, Seattle, United States of America. Fabio Trincardi is Senior Research Scientist, Istituto di Scienze Marine-Consiglio Nazionale delle Ricerche (ISMAR-CNR), Bologna, Italy. Miquel Canals is Professor, GRC Geociències Marines, Universitat de Barcelona, Spain. 
These original goals have been somewhat modified and expanded as the EU-NA program matured.

This special issue celebrates the burgeoning EU-NA collaboration on continental margin science. The EC (through Mr. Gilles Ollier) and the U.S. ONR (through Dr. Tom Drake) are happy to support this special issue of Oceanography. While the issue focuses on the EC-ONR project EuroSTRATAFORM and its affiliated projects (EUROSTRATAFORM, PASTA, EURODELTA, PREMISE, and PROMESS 1), the issue also addresses other major efforts (HERMES, EURODOM, and COS-
TA). The design of this issue demonstrates that when three rapidly advancing technologies are deployed, in concert, by marine scientists, they can (1) map the character of the seabed and the sedimentary architecture that lies buried beneath, (2) monitor the ocean bed at numerous spatial and temporal scales, and (3) model/ simulate the evolution of the seafloor both at numerous spatial and temporal scales. This union of technologies has greatly expanded our view and understanding of the seafloor and its evolution. 四

\section{EuroSTRATAFORM ....European Margin Strata Formation}

Responses of Margin Sedimentation to Natural and Human Impacts

\section{EUROSTRATAFORM AFFILIATED PROJECTS}

EURODELTA.....European Coordination on Mediterranean Prodeltas

EUROSTRATAFORM.....A solely European research-based version of EurOSTRATAFORM

PASTA.....Po and Apennine Sediment Transport and Accumulation

PREMISE.....PREdictive Modeling In Support of EuroSTRATAFORM

PROMESS 1.....Profiles Across Mediterranean Sediment Systems: Part 1

\section{RELATED PROJECTS}

COSTA.....Continental Slope Stability

HERMES..... Hotspot Ecosystem Research on the Margins of European Seas

EURODOM.....EUROpean Deep Ocean Margins 